\title{
Antioxidant and Proliferative Activities of Bupleuri Radix Extract Against Serum Deprivation in SH-SY5Y Cells
}

\author{
Mi Kyoung Seo,3, Hye Yeon $\mathrm{Cho}^{3}$, Chan Hong Lee ${ }^{3}$, Kyung Ah Koo ${ }^{4}$, Yong Ki Park', \\ Jung Goo Lee $e^{1,2,3}$, Bong Ju Lee ${ }^{1,2}$, Sung Woo Park ${ }^{3 凶}$ and Young Hoon Kim ${ }^{1,2,3 凶}$ \\ 'Department of Psychiatry, Inje University School of Medicine, Busan, Republic of Korea \\ 2Department of Psychiatry, Haeundae Paik Hospital, Inje University, Busan, Republic of Korea \\ ${ }^{3}$ Paik Institute for Clinical Research, Inje University, Busan, Republic of Korea \\ ${ }^{4}$ Department of Biological Science, University of the Science in Philadelphia, Philadelphia, PA, USA \\ ${ }^{5}$ College of Oriental Medicine, Dongguk University, Gyeongju, Republic of Korea
}

Objective Bupleuri Radix (BR) is a major component of several Oriental herbal medicines used to treat stress and mental illness. There are evidences that antidepressant drugs modulate oxidative damage implicated in the pathophysiology of neuropsychiatric disorder, including depression. The aim of the present study was to investigate antioxidant and proliferative effects of BR against oxidative stress induced by serum deprivation in SH-SY5Y cells.

Methods We examined the antioxidant effects of BR on a number of measures, including cell viability, formation of reactive oxygen species (ROS), superoxide dismutase (SOD) activity and levels of both Bcl-2 and Bax. We also investigated the effects of BR on cell proliferation using the bromodeoxyuridine (BrdU) assay, and used Western blot analysis to measure changes in expression of the cell cycle phase regulators.

Results 1) Serum deprivation significantly induced the loss of cell viability, the formation of ROS, the reduction of SOD activity, down-regulation of Bcl-2 expression and up-regulation of Bax expression. However, BR extract reversed these effects in dose-dependent manner. 2) Serum deprivation significantly reduced cell proliferation. Western blot analysis revealed that serum deprivation significantly decreased cyclinD1 and phosphorylated retinoblastoma (pRb) expression, and increased p27 expression. On the other hand, BR dose dependently reversed these effects.

Conclusion This study suggests that aqueous extract of BR may exert potent antioxidant effects and also play an important role in regulating cell cycle progression during neurogenesis. These effects of BR may be a potentially important mechanism of antidepressant underlying the observed antioxidant and proliferative effects.

Psychiatry Investig 2013;10:81-88

Key Words Bupleuri Radix, Antioxidant effect, Proliferative effect, Antidepressant.

\section{INTRODUCTION}

The pathophysiology of several neuropsychiatric disorders

Received: September 13, 2012 Revised: November 6, 2012

Accepted: November 6, 2012 Available online: January 24, 2013

$\triangle$ Correspondence: Sung Woo Park, PhD

Paik Institute for Clinical Research, Inje University, 75 Bokji-ro, Jin-gu, Busan 614-735, Republic of Korea

Tel: +82-51-890-6749, Fax: +82-51-894-6709

E-mail: swpark@inje.ac.kr

$\triangle$ Correspondence: Young Hoon Kim, MD, PhD

Department of Psychiatry, Haeundae Paik Hospital, Inje University, 875

Haeundae-ro, Haeundae-gu, Busan 612-896, Republic of Korea

Tel: +82-51-890-6749, Fax: +82-51-894-6709

E-mail: neuro109@hanmail.net

(a) This is an Open Access article distributed under the terms of the Creative Commons Attribution Non-Commercial License (http://creativecommons.org/licenses/bync/3.0) which permits unrestricted non-commercial use, distribution, and reproduction in any medium, provided the original work is properly cited. including depression is accompanied by increased oxidative stress. ${ }^{1,2}$ Oxidative stress is caused by an imbalance between levels of free radicals production and efficiency of the antioxidant enzyme system to neutralize and eliminate reactive oxygen species (ROS). Free-radical damage by ROS, such as the superoxide anion and hydrogen peroxide, is the primary source of oxidative stress. The excessive accumulation of ROS and inefficiency of the antioxidant enzyme system can damage DNA and induce lipid peroxidation and protein modification, causing cellular dysfunction and even apoptosis. ${ }^{3,4}$ In the brain, the main antioxidant enzymes are superoxide dismutase (SOD), catalase (CAT) and glutathione peroxidase (GSH-Px). SOD is the most important enzyme for the detoxification of ROS and protects against oxidative stress and thus can help prevent neuronal cell apoptosis. ${ }^{5}$ Some antide- 
pressant have been demonstrated to up-regulate activities of SOD, CAT, glutathione S-transferase (GST) and glutathione reductase (GR), as a possible target in the action of antidepressants, in animal model of stress and patients with depression. ${ }^{6-8}$ Moreover, in vivo study demonstrated that antidepressants can upregulate antiapoptotic protein B cell lymphoma protein-2 (Bcl-2) and downregulate proapoptotic Bcl-2-associated X protein (Bax). ${ }^{9}$ Therefore, antidepressants may exert neuroprotective effects by reducing apoptotic cell death via augmentation of antioxidant activity. This enhanced neuroprotection may contribute to the therapeutic effects produced by antidepressant drug treatment.

Herbal medicines have been used for centuries in a number of Asian countries for the treatment of various neuropsychiatric disorders. In particular, Kami-shoyo-san (KSS) is a popular traditional medicine used in Korea, Japan, and China for treating stress-related neuropsychiatric disorders such as depression or anxiety. ${ }^{10,11}$ We previously reported that KSS, a combinatorial preparation of Paeoniae Radix, Bupleuri Radix, Atractylodis Macrocephalae Rhizoma, Liriopis Tuber, Angelicae Gigantis Radix, Hoelen, Menthae Folium, Glycyrrhizae Radix and Zingiberis Rhizoma, produces antidepressant-like effects at both behavioral and molecular levels. ${ }^{12}$ Bupleuri Radix (BR), a major component of KSS, is also frequently included in herbal formulas designed to treat stress and mental illness. ${ }^{13}$ The major chemical constituents of BR have been known to saikosaponin, adonitol, $\alpha$-spinasterol and other volatile oils, and aqueous extracts of this herb have been shown to have affinity for the $5-\mathrm{HT}_{1 \mathrm{~A}}$ and dopamine $\mathrm{D}_{2}$ receptor. ${ }^{14,15}$ Recently, we provided some evidences for the antidepressantlike effects of BR extract in vivo and in vitro ${ }^{16}$ : BR treatment significantly reduced the immobility time in the forced swimming test in rats; BR treatment significantly upregulated CREB and BDNF expression, two major targets of antidepressant action, through actions on the phosphatidylinositol 3-kinase (PI3K)-mediated Akt/Glycogen synthase Kinase-3 $\beta$ (GSK$3 \beta$ ) signaling pathways in human neuroblastoma SH-SY5Y cells.

It is well documented that long-term (two to four week) antidepressant administration enhances cell proliferation in adult rat hippocampus, consistent with the time course for the therapeutic action of antidepressant drugs. Furthermore, antidepressant treatment is reported to block or reverse the downregulation of neurogenesis caused by stress. ${ }^{17}$ However, the molecular mechanisms that regulate these processes remain unclear. Many reports suggest that the neuroproliferative effects of antidepressants may be due to actions on the cAMP/ PKA, MAPK and Wnt signaling pathways. ${ }^{18-20}$ Shors et al. ${ }^{21}$ demonstrated that inhibition of neurogenesis with a chemical cell cycle inhibitor blocked hippocampal-dependent learning.
The PI3K/Akt signaling pathway promotes cell cycle progression through inhibition of GSK-3 $\beta$, leading to elevated expression of cyclin D1 and phosphorylated retinoblastoma (pRb), positive G1/S phase cell cycle regulators, and reduced levels of p27, a negative regulator of the G1/S phase of the cell cycle. ${ }^{22}$ Accordingly, this signaling may regulate hippocampal neurogenesis in the adult brain and be, therefore, another potential target for antidepressant drugs.

The aim of the present study was to explore possible antioxidant activity of BR on SH-SY5Y cells after serum deprivationinduced oxidative stress by assessing changes in ROS formation, SOD activity, as well as Bcl-2 and Bax levels. Next, we determined whether BR promotes cell proliferation via modulation of the G1/S phase regulators cyclin D1, pRb and p27 in SH-SY5Y cells following serum deprivation.

\section{METHODS}

\section{Materials}

Dulbecco's modified Eagle's medium (DMEM), fetal bovine serum (FBS) and antibiotic-antimycotic were purchased from GIBCO BRL (Grand Island, NY, USA). 3-[4,5-dimethylthiazol-2-yl]-2,5-diphenyltetrazolium bromide (MTT) and dichlorofluorescin diacetate (DCFH-DA) was obtained from Sigma. Antibodies used for western blotting were obtained from the following sources: anti-Bax and anti-Bcl-2 were obtained from Santa Cruz Biotechnology (Santa Cruz, CA, USA); anticyclin D1, anti-phosphorylated Rb (Ser 780) and anti-p27 from Cell Signaling Technology (Cell Signaling, Beverly, MA, USA); anti- $\alpha$-tubulin was purchased from Sigma; ECL antimouse IgG, horseradish peroxidase linked species-specific whole antibody from Amersham Pharmacia (Amersham, Little Chalfont, Buckinghamshire, UK) and anti-goat and antirabbit IgG-horseradish peroxide conjugates from Santa Cruz Biotechnology. The SOD enzyme assay kit was purchased from Cayman Chemical (Ann Arbor, MI, USA). Cell proliferation was measured using the 5-Bromo-2'-deoxy-uridine (BrdU) labeling and detection kit from Roche Molecular Biochemicals (Indianapolis, IN, USA). All other chemicals were purchased from commercial sources.

\section{Plant material}

Bupleuri Radix root was authenticated by Dr. Y.-K. Park, one of the authors. A voucher specimen (BR-W-0303) was deposited in the College of Oriental Medicine, Dongguk University herbarium.

\section{Preparation of Bupleuri Radix extracts}

BR was air dried and extracts were prepared by boiling sample in $200 \mathrm{~mL}$ water at $100^{\circ} \mathrm{C}$ for $2 \mathrm{~h}$. The procedure was 
repeated twice. The extracts were then filtered, concentrated using a vacuum evaporator, and lyophilized into powder. The total extract yield was $20 \%$ (w/w).

\section{Cell culture}

SH-SY5Y human neuroblastoma cells, obtained from the American Type Tissue Culture Collection (Rockville, MD, USA), were cultured in medium with an equal amount of Dulbecco's modified essential medium (DMEM) supplemented with $10 \%$ heat-inactivated fetal bovine serum and $1 \%$ antibiotic-antimycotic. The cells were maintained in a humidified atmosphere of $5 \% \mathrm{CO}_{2}$ at $37^{\circ} \mathrm{C}$. The culture medium was changed every two or three days. BR extract was dissolved in distilled water (DW) and diluted with DMEM medium to a concentration of $1,000 \mathrm{mg} / \mathrm{mL}$. Cells were treated with various concentrations of BR extract (10, 100, and 1,000 $\mu \mathrm{g} / \mathrm{mL})$.

\section{Western blotting}

Cells were plated at a density of $2 \times 10^{6}$ cells per $100-\mathrm{mm}$ dish. After incubation for $24 \mathrm{~h}$, cells were treated with various concentrations of BR extract for $72 \mathrm{~h}$. Whole cell lysates were prepared as follows: cells were washed twice with ice-cold phosphate buffered saline (PBS). Lysis buffer [20 mM Tris$\mathrm{HCl}, 137 \mathrm{mM} \mathrm{Nacl}, 10 \%$ glycerol, $1 \%$ Nonidet p-40, 0.1\% sodium dodecyl sulfate (SDS), $0.5 \%$ Sodium deoxycholate, 2 mM EDTA, 1 tablet complete protease inhibitor (Roche, Laval, Quebec, Canada), $20 \mathrm{mM} \mathrm{NaF}$ and $1 \mathrm{mM} \mathrm{Na}_{3} \mathrm{VO}_{4}$ ] was then added, followed by centrifugation $\left(1,000 \times \mathrm{g}, 10 \mathrm{~min}, 4^{\circ} \mathrm{C}\right)$. Equal amounts of protein $(20 \mu \mathrm{g})$ from the cell extracts in each treatment condition were separated using SDS polyacrylamide gel electrophoresis and then transferred electrophoretically onto polyvinylidene fluoride (PVDF) membranes. PVDF membranes were blocked by incubation in $5 \%(\mathrm{w} / \mathrm{v})$ nonfat milk in Tris buffered saline (TBS) with $0.15 \%$ Tween 20 (TBS$\mathrm{T})$ for $1 \mathrm{~h}$. After incubation with a primary antibody (Bcl-2, 1 : 500; anti-Bax, 1 : 500; anti-cyclin D1, 1 : 1,000; anti- phosphor$\operatorname{ser}^{780}$ - Rb, 1 : 1,000; anti-p27, $1: 1,000$; anti- anti- $\alpha$-tubulin, 1 : $2,000)$ in TBS- $\mathrm{T}$ at $4^{\circ} \mathrm{C}$ overnight, the membranes were washed three times in TBS-T for $10 \mathrm{~min}$. The membranes were then incubated for $1 \mathrm{~h}$ in TBS-T containing the horseradish peroxidase-conjugated secondary antibody (anti-cyclin D1, 1 : 2,000, anti-phosphor-ser ${ }^{780}$ - Rb, $1: 2,000$, and anti-p27, 1 : 2,000; ECL anti-mouse IgG for anti-Bcl-2, $1: 500$, anti-Bax, 1 : 500, and anti- $\alpha$-tubulin, $1: 10,000)$. Immunoreactive bands were visualized and quantified using ECL+ Western blotting reagents, with chemifluorescence detected by Las-3,000 Image Reader (Fuji Film, Tokyo, Japan) software. Protein levels were normalized to the housekeeping protein $\alpha$-tubulin to adjust for variability of protein loading and expressed as the percentage of vehicle control (deemed to be 100\%).

\section{Cell viability assay}

Cell viability was measured using the MTT assay. SH-SY5Y cells were seeded on 96 -well plates at a density $2 \times 10^{4}$ cells per well, and then cultured for $72 \mathrm{~h}$ in media with or without serum, with various concentrations of BR extract dissolved in DW. Cell viability was then determined using colorimetric measurement of the reduction product of MTT. The culture medium was removed, $100 \mu \mathrm{L}$ of a DMSO solution was added to each well, and the plates incubated at $37^{\circ} \mathrm{C}$ for $4 \mathrm{~h}$ to dissolve the formazan that had formed. Reduced MTT was measured on an ELISA reader (SLT Spectra; SLT Instruments, Salzburg, Austria) at a wavelength of $570 \mathrm{~nm}$. Values for each treatment group are expressed as a percentage of the control.

\section{ROS activity}

To measure the ROS production in SH-SY5Y cells produced by serum withdrawal, we used the DCFH-DA method described as follows. DCFH-DA is a fluorescent dye that crosses the cell membrane and is enzymatically hydrolyzed by intracellular esterases to nonfluorescent 2',7'-dichlorofluorescein $(\mathrm{DCFH})$. Cells were plated at a density of $1 \times 10^{4}$ cells per 96-well dish. After $48 \mathrm{~h}$, cells were treated with DCFH-DA at a final concentration of $100 \mu \mathrm{M}$ in DMEM for $1 \mathrm{~h}$ at $37^{\circ} \mathrm{C}$ and then washed with PBS. The cells were then treated with various concentrations of BR extract. ROS levels were measured $72 \mathrm{~h}$ later using a kinetic microplate reader (Bio-teksynerge HT, Instruments, USA) at wavelengths of $485 \mathrm{~nm}$ (excitation) and $535 \mathrm{~nm}$ (emission). Values for each treatment group are expressed as a percentage of the control.

\section{SOD enzyme activity}

Cells were plated at a density of $1 \times 10^{6}$ cells per $100-\mathrm{mm}$ dish. After $24 \mathrm{~h}$ of incubation, the cells were treated with various concentrations of BR extract for $72 \mathrm{~h}$. For whole cell lysates, the cells were washed twice with ice cold phosphate buffered saline (PBS). Lysis buffer was added, followed by centrifugation $\left(1,000 \times \mathrm{g}, 10 \mathrm{~min}, 4^{\circ} \mathrm{C}\right)$. Equal $20 \mu \mathrm{L}$ lysate aliquots were used for determination of SOD enzyme activity as per the manufacturer's instructions (Superoxide Dismutase Assay Kit, Cayman Chemical Company, USA). Reduced SOD was measured using an ELISA reader (SLT Spectra; SLT Instruments, Salzburg, Austria) at a wavelength of $450 \mathrm{~nm}$. Values for each treatment group are expressed as a percentage of the control.

\section{Cell proliferation assay}

The BrdU labeling and detection kit (Cell Proliferation ELISA, Roche, Germany) was used for the quantitative determination of BrdU incorporated into cellular DNA. Cells were grown in a 96-well microplate and were incubated with BR ex- 
tract at the concentrations indicated for $72 \mathrm{~h}$, after which the BrdU assay was performed. The extent of the reaction was measured using an ELISA reader at 370 and $492 \mathrm{~nm}$ (Bioteksynerge HT, Instruments, USA). Values for each treatment group are expressed as a percentage of the control.

\section{Statistical analysis}

Statical analyses were carried out using repeated-measures one-way ANOVA followed by Scheffe's post-hoc tests. $p$ values $\leq 0.05$ were deemed to be statistically significant.

\section{RESULTS}

\section{Antioxidant effects of Bupleuri Radix}

\section{Effects of Bupleuri Radix on cell viability}

To assess the protective effect of BR on serum deprivationinduced cytotoxicity, we analyzed cell viability using the MTT assay. Serum deprivation reduced cell viability to about $38 \%$ of control values $(\mathrm{p}<0.01)$ (Figure 1$)$. This toxic effect of serum deprivation was significantly attenuated by BR treatment in a dose-dependent manner $(\mathrm{p}<0.01)$ (Figure 1).

\section{Effect of Bupleuri Radix on ROS formation and SOD activity}

To examine whether the protective effect of BR on serum deprivation-induced toxicity are mediated through antioxidant actions, intracellular ROS levels were quantified using the DCFH-DA assay and SOD activity was measured using a commercially available kit. Following serum withdrawal, ROS levels were greately increased, to about $442 \%$ of control values $(\mathrm{p}<0.01)$ (Figure 2A). BR treatment dose-dependently

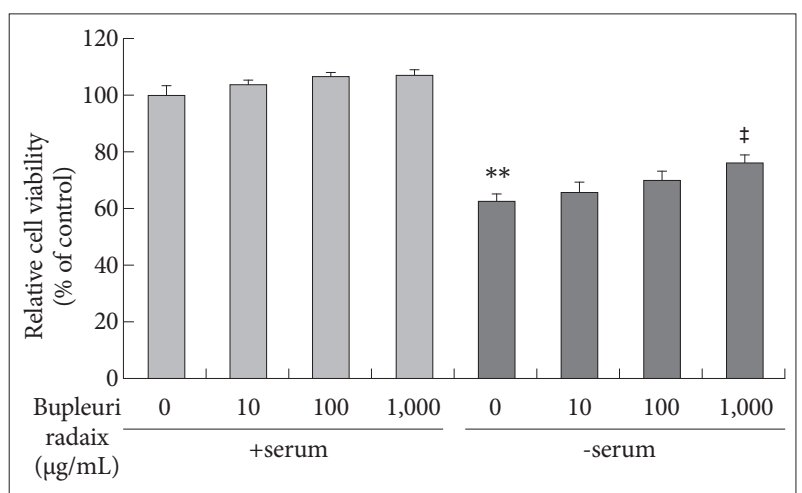

Figure 1. Effects of Bupleuri Radix on the cell viability in $\mathrm{SH}$ SY5Y cells. Cells were treated with different doses of Bupleuri Radix for $72 \mathrm{~h}$ with (+serum) or without serum (-serum), after which the 3-[4,5-dimethylthiazol-2-yl]-2,5-diphenyltetrazolum assay was performed. Values are expressed as a percentage of control (serum-normal, no drug treatment) and represent means \pm S.E.M. from the three independent experiments. ${ }^{* *} p<0.01$ vs. untreated control, ${ }^{\ddagger} p<0.01$ vs. serum starved-alone. suppressed serum withdrawal-induced ROS generation $(\mathrm{p}<$ 0.01)(Figure 2A).

SOD activity was decreased to $28 \%$ of control levels after serum deprivation $(\mathrm{p}<0.01)$ (Figure $2 \mathrm{~B})$. BR treatment prevented the serum withdrawal-induced decrease in SOD activity in a dose-dependent manner $(\mathrm{p}<0.01)$ (Figure $2 \mathrm{~B})$. Moreover, treatment with $\mathrm{BR}$ at $100 \mu \mathrm{g} / \mathrm{mL}$ and $1,000 \mu \mathrm{g} / \mathrm{mL}$ significantly increased SOD activity by $23 \%$ and $36 \%$, respectively, under serum-normal conditions $(\mathrm{p}<0.01)$ (Figure $2 \mathrm{~B}$ ).

\section{Effects of Bupleuri Radix on the levels of Bcl-2 and Bax}

We also investigated whether BR has antiapoptotic effects on Bcl-2 and Bax expression under oxidative stress conditions caused by serum deprivation. Bcl-2 expression was significantly reduced by about $34 \%$ in serum-deprived cells, compared to control conditions $(\mathrm{p}<0.01)$ (Figure $3 \mathrm{~A})$. BR treatment restored $\mathrm{Bcl}-2$ expression almost to control values $(\mathrm{p}<$ 0.05 or $\mathrm{p}<0.01$ )(Figure $3 \mathrm{~A}$ ). In the presence of serum, treat-

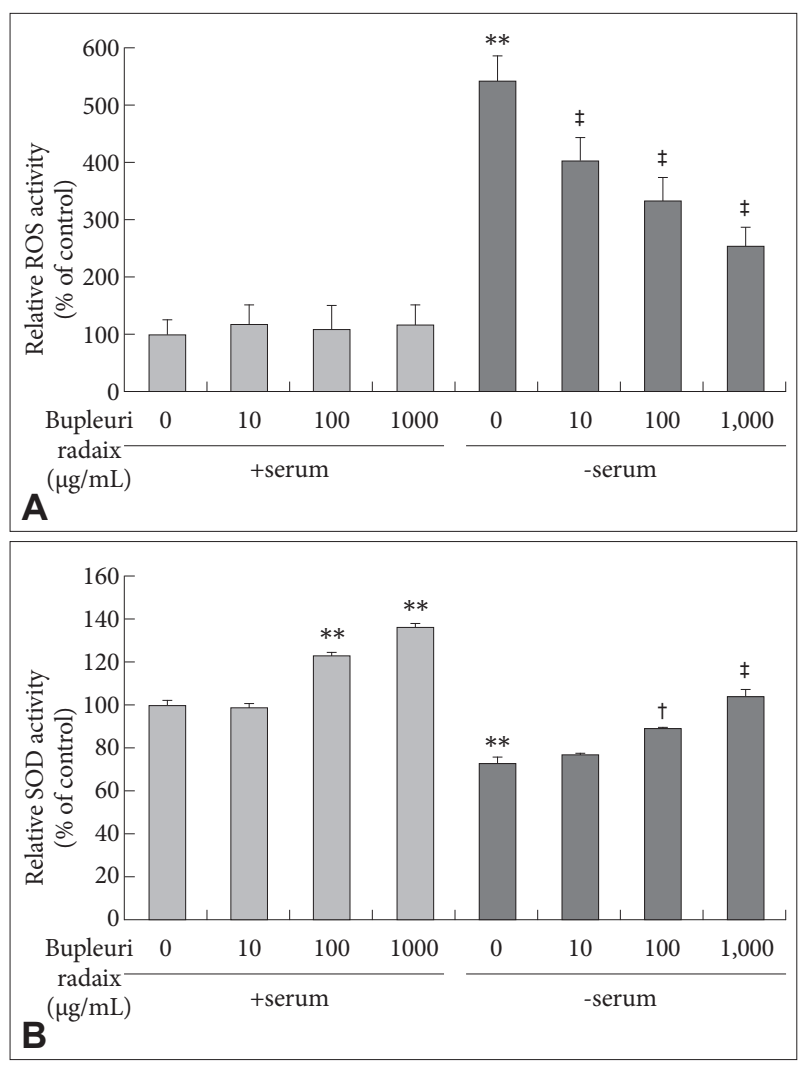

Figure 2. Effects of Bupleuri Radix on ROS formation and SOD activity in SH-SY5Y cells. Cells were treated with different doses of Bupleuri Radix for $72 \mathrm{~h}$ with (+serum) or without serum (-serum). The fluorescence intensity of dichlorofluorescin diacetate was measured (A). SOD activity was assessed as described in the Methods (B). Values are expressed as a percentage of control (serum-normal, no drug treatment) and represent means \pm S.E.M. from the three independent experiments. ${ }^{* *} p<0.01 \mathrm{vs}$. untreated control, ${ }^{\dagger} p<0.05$ vs. serum starved-alone, ${ }^{\ddagger} p<0.01$ vs. serum starved-alone. ROS: reactive oxygen species, SOD: superoxide dismutase. 

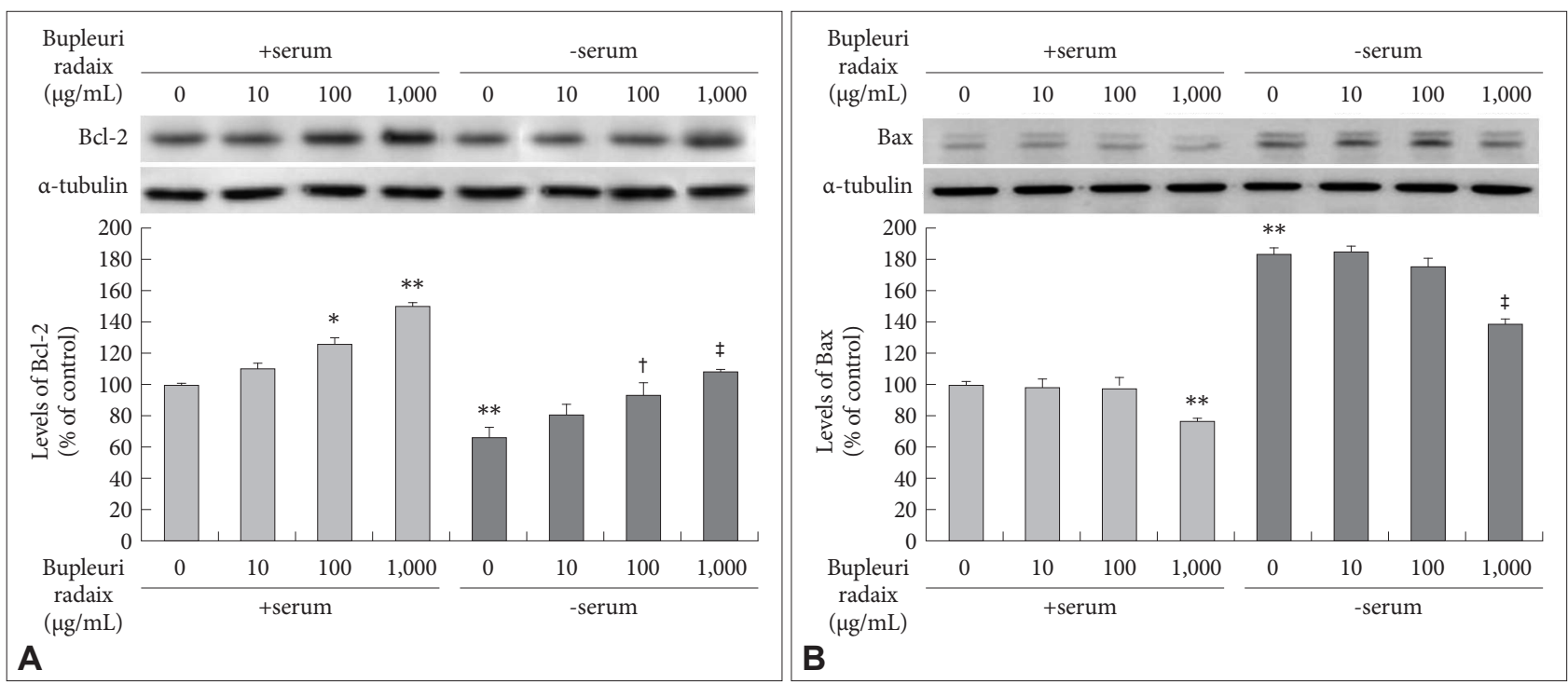

Figure 3. Effects of Bupleuri Radix on Bcl-2 and Bax expression in SH-SY5Y cells. Cells were treated with different doses of Bupleuri Radix for $72 \mathrm{~h}$ with (+serum) or without serum (-serum). Cell lysates were analyzed by SDS-PAGE and Western blotting with anti-Bcl-2 (A) and antiBax (B) primary antibodies. A representative image and quantitative analysis normalized to the $\alpha$-tubulin band are shown. Values are expressed as a percentage of the control (serum-normal, no drug treatment) and represent means \pm S.E.M. from the three independent experiments. ${ }^{*} p<0.05$ vs. untreated control, ${ }^{* *} p<0.01$ vs. untreated control, ${ }^{\dagger} p<0.05$ vs. serum starved-alone, ${ }^{\ddagger} p<0.01$ vs. serum starved-alone. Bcl-2: B cell lymphoma protein-2, Bax: Bcl-2-associated X protein.

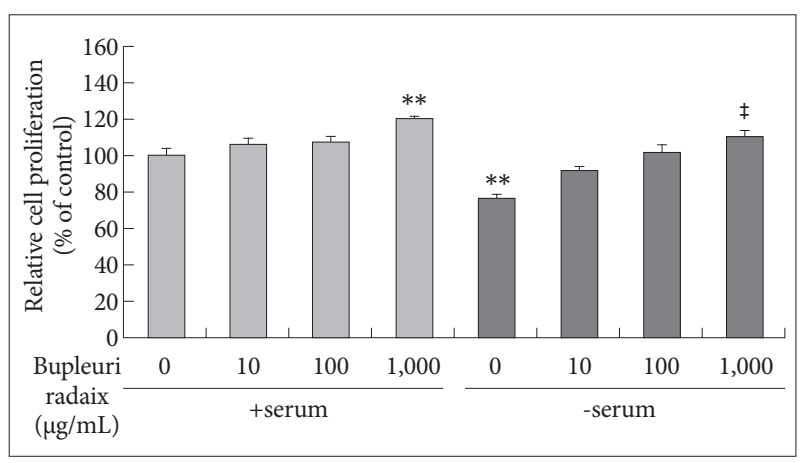

Figure 4. Effects of Bupleuri Radix on SH-SY5Y cell proliferation. Cell were treated with different doses of Bupleuri Radix for $72 \mathrm{~h}$ with (+serum), or without serum (-serum), after which the BrdU assay was performed. Values are expressed as a percentage of control (serum-normal, no drug treatment) and represent means $\pm S$. E.M. from the three independent experiments. ${ }^{* *} p<0.01$ vs. untreated control, ${ }^{\ddagger} p<0.01$ vs. serum starved-alone. BrdU: bromodeoxyuridine.

ment with $\mathrm{BR}$ increased Bcl-2 expression in dose-dependent manner $(\mathrm{p}<0.05$ or $\mathrm{p}<0.01)$ (Figure $3 \mathrm{~A})$. Conversely, serum deprivation increased Bax by $84 \%$, compared to control values $(\mathrm{p}<0.01)$ (Figure $3 \mathrm{~B})$, and $\mathrm{BR}$ treatment attenuated the serum withdrawal-induced increase in Bax expression $(\mathrm{p}<0.01)$ (Figure 3B). BR treatment also significantly reduced Bax levels under serum-normal conditions ( $\mathrm{p}<0.01$ )(Figure $3 \mathrm{~B}$ ).

\section{Cell proliferative effect of Bupleuri Radix}

Effects of Bupleuri Radix on cell proliferation

To examine the effect of BR on cell proliferation, we used the BrdU incorporation method, which detects cell division by measuring new DNA synthesis. As shown in Figure 4, under serum-free conditions BrdU incorporation significantly decreased to about $23 \%$ of control values $(\mathrm{p}<0.01)$. However, under the same conditions BR treatment stimulated BrdU incorporation in a dose-dependent manner $(\mathrm{p}<0.01)$ (Figure 4). In the presence of serum, BR at $1,000 \mu \mathrm{g} / \mathrm{mL}$ increased BrdU incorporation by $20 \%$ compared to control levels $(\mathrm{p}<0.01)$.

\section{Effects of Bupleuri Radix on cyclin D1, phosphorylated $\mathrm{Rb}$, and $\mathrm{p} 27$ expression}

As shown in Figure 5, serum deprivation reduced cyclin D1 and pRb expression to $54 \%$ and $33 \%$ of control, respectively $(\mathrm{p}<0.05$ and $\mathrm{p}<0.01$ )(Figure $5 \mathrm{~A}$ and $\mathrm{B})$. However, under the same conditions $B R$ treatment significantly increased cyclin $\mathrm{D} 1$ expression $(\mathrm{p}<0.01)$ (Figure $5 \mathrm{~A})$ and $\mathrm{pRb}$ expression $(\mathrm{p}<0.05)$ (Figure $5 \mathrm{~B})$, as compared to the control. In addition, BR treatment $(1000 \mu \mathrm{g} / \mathrm{mL})$ increased pRb levels by $19 \%$ under the serum-normal condition ( $\mathrm{p}<0.05)$ (Figure $5 \mathrm{~B}$ ).

Seurm deprivation also upregulated the cyclin-dependent kinase inhibitor p27 ( $<<0.05)$ (Figure 5C). In contrast, stimultaneous treatment with $\mathrm{BR}$ prevented this increase in p27 levels, and the supressive effect was proportional to the concentration of BR used ( $<<0.05$ )(Figure 5C).

\section{DISCUSSION}

The major findings of the present study were 1) BR treatment improved cellular antioxidant defenses by affecting ROS 


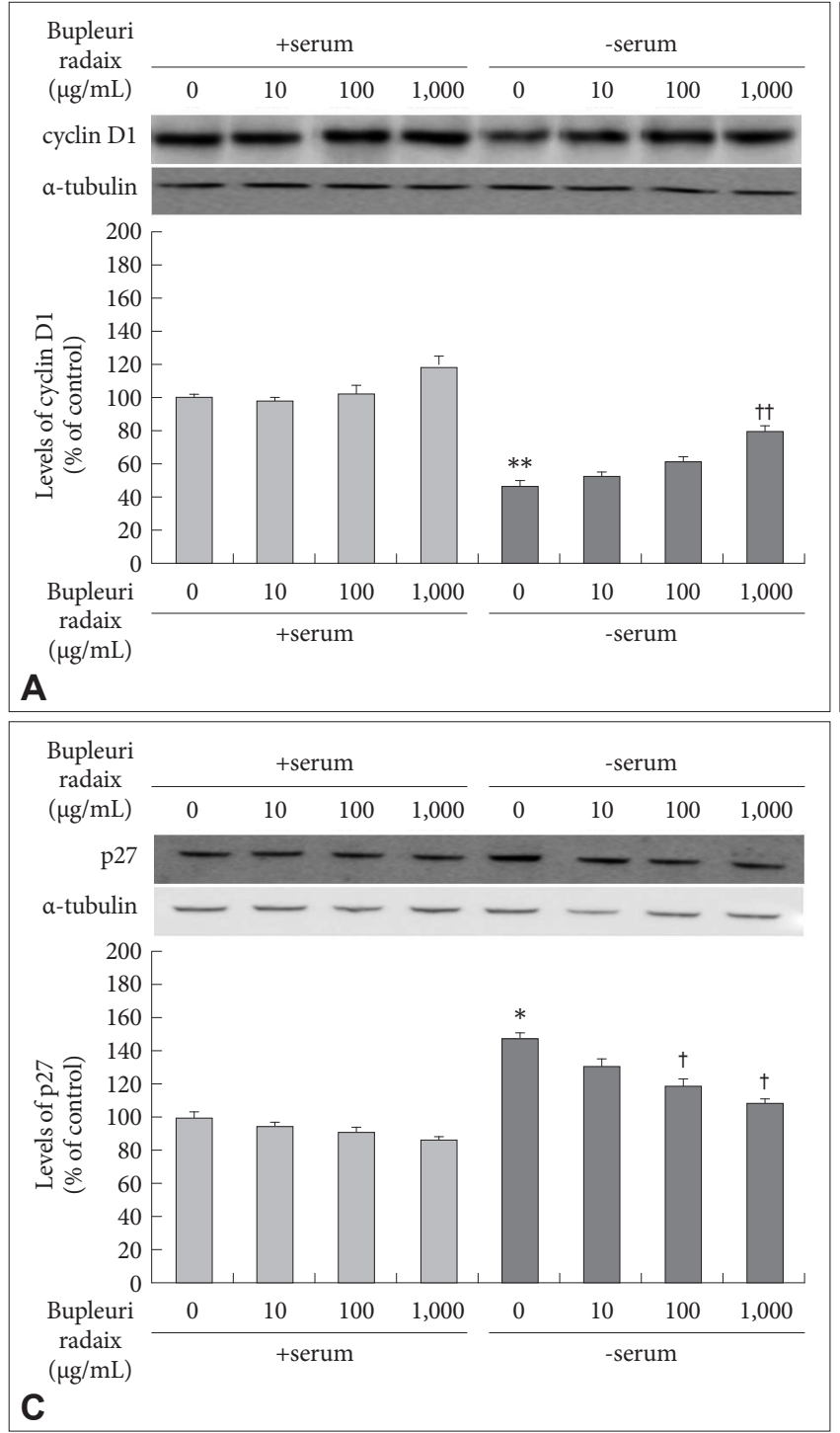

levels, SOD activity, and Bcl-2 and Bax expression to provide protective effects against oxidative stress and oxidative stressinduced apoptosis; 2) BR treatment promoted cell proliferation via stimulation of cell cycle progression by modulating the $\mathrm{G} 1 / \mathrm{S}$ phase regulators cyclin $\mathrm{D} 1, \mathrm{pRb}$ and $\mathrm{p} 27$.

Oxidative stress caused by serum deprivation play a causal role in the induction of apoptosis. ${ }^{23}$ Cell death induced by serum deprivation usually manifests as the hallmark features of apoptosis, including DNA laddering, activation of caspases 3 and 9, cytochrome $c$ release, increased levels of bax, and decreased Bcl-2 levels, NF-kappa B (NF- $\kappa \mathrm{B})$ binding activity, and cellular glutathione levels. ${ }^{24}$ The present study showed that serum deprivation attenuated cell viability and induced a large increase of ROS production, reduced SOD activity, the down-regluation of antiapoptotic protein Bcl-2, and up-regulation of pro-apoptotic protein Bax in SH-SY5Y cells.

Antioxidant effects are another putative mechanism of an-

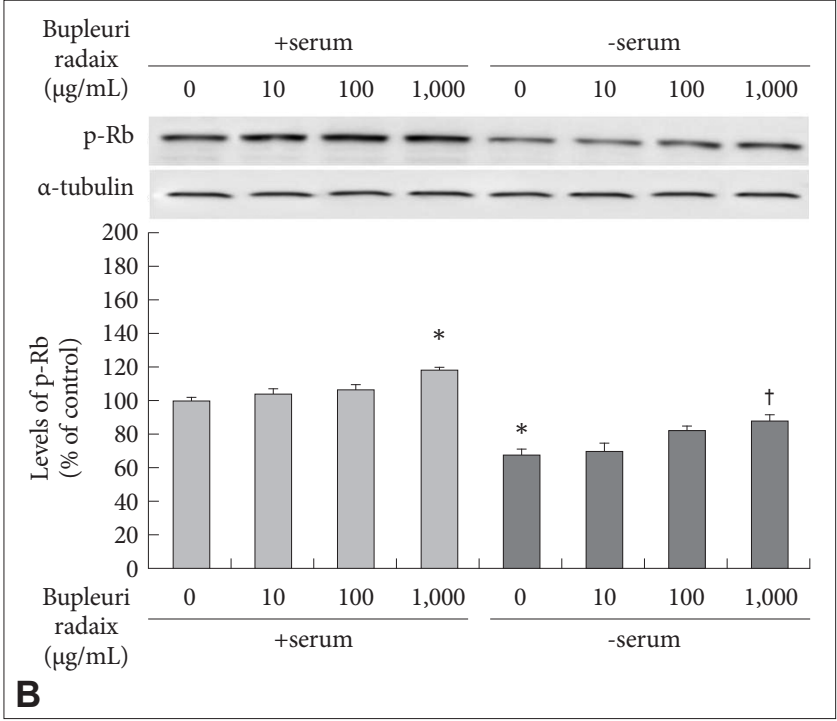

Figure 5. Effects of Bupleuri Radix on cyclin D1, phosphorylated Rb, and $\mathrm{p} 27$ expression in SH-SY5Y cells. Cell were treated with different doses of Bupleuri Radix for $72 \mathrm{~h}$ with (+serum) or without serum (-serum). Cell lysates were analyzed by SDS-PAGE and Western blotting with anti-cyclin D1 (A), anti-pRb (B), and anti-p27 (C) primary antibodies. A representative image and quantitative analysis normalized to the a-tubulin band are shown. Values are expressed as a percentage of control (serum-normal, no drug treatment) and represent means \pm S. E.M. from the three independent experiments. ${ }^{*} p<0.05$ vs. untreated control, ${ }^{* *} p<0.01$ vs. untreated control, ${ }^{\dagger} p<0.05$ vs. serum starvedalone, ${ }^{+t} p<0.01$ vs. serum starved-alone. $p R b$ : phosphorylated retinoblastoma.

tidepressant action. Previous studies have shown that antidepressants drugs can modulate depression-induced oxidative stress in vivo. ${ }^{7,25}$ Other reports have suggested that the neuroprotective actions of antidepressant drugs, such as amitriptyline, venlafaxine and fluoxetine, rely on upregulation of SOD activity. ${ }^{26,27}$ In addition, elevated levels of ROS can lead to apoptotis. ${ }^{28} \mathrm{Bax}$ and Bcl-2 play key roles in the effects of ROS on the mitochondrial apoptotic pathway. ${ }^{29,30}$ Thus, whereas Bcl-2 prevents apoptosis via blockade of ROS production in mitochondria, Bax increases mitochondrial ROS production and promotes apoptosis. ${ }^{29,30}$ The present study demonstrated that BR blocked cell death, ROS production, the reduction of SOD activity, overexpression of Bax and reduction of Bcl-2 following serum withdrawal-induced oxidative stress. Consistent with these results, one study reported that the antidepressant drugs amitriptyline and tanylcypromine prevented ROS formation, glutathione depletion, Bax overexpression and 
$\mathrm{Bcl}-2$ reduction due to $\mathrm{MPP}^{+}$toxicity in differentiated $\mathrm{PC} 12$ cells. ${ }^{31}$ Based on these findings, we postulate that the effects of $\mathrm{BR}$ on serum withdrawal-induced oxidative stress can be partially explained through alteration of the balance between Bcl-2 and Bax, and that BR may exert neuroprotective effects via its antioxidant and antiapoptotic properties.

CREB and BDNF are known to play prominent roles in neurogenesis. As such, upregulation of CREB and BDNF could mediate the effects of antidepressant treatment by increasing neurogenesis and modulating survival signals. ${ }^{32}$ Supporting this notion, Monstany et al. ${ }^{20}$ provide evidence that antidepressant drugs enhance hippocampal cell proliferation. They reported an increase in nuclear $\beta$-catenin and cytosolic Akt levels in venlafaxine-treated animals, suggesting that antidepressants activate the intracellular signaling through Wnt $(\beta$ catenin translocation) and Akt pathways, which could then increase the expression of genes regulating the cell cycle. $\beta$-catenin, in particular, has been shown to modulate the cell cycle regulators myc and cyclin D1. ${ }^{33,34}$ Furthermore, regulation of cell cycle progression involves the PI3K/Akt/GSK-3 $\beta$ pathway. Thus, PI3K/Akt-mediated phosphorylation of GSK$3 \beta$ leads to nuclear accumulation of cyclinD1, promoting cell cycle progression, and enhances degradation of cyclin-dependent kinase inhibitor p27, a negative regulator of the cell cycle. ${ }^{22,35}$ During the G1/S phase, Rb phosphorylation releases the E2F transcription factor from an inhibitory Rb complex, which then activates genes required for cell cycle progression. ${ }^{36}$ The present study demonstrates that BR extract were highly effective on preventing the reduction of cell proliferation and cyclin D1 and pRb expression and the elevation of p27 levels induced by oxidative stress in SH-SY5Y cell. According to Hse et al. ${ }^{37,38}$ the saponin-enriched BR fraction exerted antiproliferative activity by inducing apoptosis and blocking G1 phase cell cycle progression in the human lung cancer cell line, A549. This discrepancy may be attributable to differences in fraction vs. extract and cancer cell line vs. neuronal cell line. The underlying mechanism of BR extract in human neuroblastoma cells was unknown. Moreover, previous our study suggested that the antidepressant-like effects of BR may be mediated by upregulation of CREB and BDNF expression via the PI3K/Akt/GSK-3 $\beta$ signaling pathways. ${ }^{16}$ A growing body of evidence shows that impaired neurogenesis is implicated in the phathogenesis of depression. ${ }^{39,40}$ However, the mechanisms concerning the effect of oxidative stress on neurogenesis remain unknown. Based on these findings, we suggest that oxidative stress induced by serum deprivation may decrease neurogenesis via downregulation of cyclin D1 and $\mathrm{pRb}$ and upregulation of $\mathrm{p} 27$, and the enhancement of cell proliferation produced by $\mathrm{BR}$ treatment may reverse these effects via PI3K/Akt/GSK-3 $\beta$ signaling.
In conclusion, BR-mediated neuroprotection may be due to inhibition of the mechanisms that lead to oxidative stress-induced apoptosis. Moreover, BR may produce antidepressantlike effects by increasing neurogenesis via regulation of cell cycle progression. These findings will help to elucidate the pharmacological action of a variety of Herbal Medicine for the treatment of mental disorders.

\section{Acknowledgments}

This study was supported by a grant of the Korea Healthcare technology R\&D Project, Ministry for Health, Welfare \& Family Affairs, Republic of Korea (A090091 to S.-W. Park).

\section{REFERENCES}

1. Herken H, Gurel A, Selek S, Armutcu F, Ozen ME, Bulut M, et al. Adenosine deaminase, nitric oxide, superoxide dismutase, and xanthine oxidase in patients with major depression: impact of antidepressant treatment. Arch Med Res 2007;38:247-252.

2. Cumurcu BE, Ozyurt H, Etikan I, Demir S, Karlidag R. Total antioxidant capacity and total oxidant status in patients with major depression: impact of antidepressant treatment. Psychiatry Clin Neurosci 2009; 63:639-645.

3. Lohr JB, Browning JA. Free radical involvement in neuropsychiatric illnesses. Psychopharmacol Bull 1995;31:159-165.

4. Stadtman ER. Role of oxidant species in aging. Curr Med Chem 2004; 11:1105-1112.

5. Greenlund LJ, Deckwerth TL, Johnson EM Jr. Superoxide dismutase delays neuronal apoptosis: a role for reactive oxygen species in programmed neuronal death. Neuron 1995;14:303-315.

6. Khanzode SD, Dakhale GN, Khanzode SS, Saoji A, Palasodkar R. Oxidative damage and major depression: the potential antioxidant action of selective serotonin re-uptake inhibitors. Redox Rep 2003;8:365-370.

7. Zafir A, Banu N. Antioxidant potential of fluoxetine in comparison to Curcuma longa in restraint-stressed rats. Eur J Pharmacol 2007;572:2331.

8. Zafir A, Ara A, Banu N. Invivo antioxidant status: a putative target of antidepressant action. Prog Neuropsychopharmacol Biol Psychiatry 2009;33:220-228.

9. Drzyzga ŁR, Marcinowska A, Obuchowicz E. Antiapoptotic and neurotrophic effects of antidepressants: a review of clinical and experimental studies. Brain Res Bull 2009;79:248-257.

10. Mantani N, Hisanaga A, Kogure T, Kita T, Shimada Y, Terasawa K. Four cases of panic disorder successfully treated with Kampo (Japanese herbal) medicines: Kami-shoyo-san and Hange-koboku-to. Psychiatry Clin Neurosci 2002;56:617-620.

11. Yamada K, Kanba S. Herbal medicine (kami-shoyo-san) in the treatment of premenstrual dysphoric disorder. J Clin Psychopharmacol 2002;22:442.

12. Park SW, Kim YK, Lee JG, Kim SH, Kim JM, Yoon JS, et al. Antidepressant-like effects of the traditional Chinese medicine kami-shoyo-san in rats. Psychiatry Clin Neurosci 2007;61:401-406.

13. Lee B, Shim I, Lee H, Hahm DH. Effect of Bupleurum falcatum on the stress-induced impairment of spatial working memory in rats. Biol Pharm Bull 2009;32:1392-1398.

14. Liao JF, Jan YM, Huang SY, Wang HH, Yu LL, Chen CF. Evaluation with receptor binding assay on the water extracts of ten CNS-active Chinese herbal drugs. Proc Natl Sci Counc Repub China B 1995;19: 151-158.

15. Wing YK. Herbal treatment of insomnia. Hong Kong Med J 2001;7: 392-402.

16. Seo MK, Song JC, Lee SJ, Koo KA, Park YK, Lee JG, et al. Antidepressant-like effects of Bupleuri Radix extract. Eur J Integr Med 2012;4:392- 
399.

17. Duman RS, Nakagawa S, Malberg J. Regulation of adult neurogenesis by antidepressant treatment. Neuropsychopharmacology 2001;25:836844 .

18. Nibuya M, Nestler EJ, Duman RS. Chronic antidepressant administration increases the expression of cAMP response element binding protein (CREB) in rat hippocampus. J Neurosci 1996;16:2365-2372.

19. Fumagalli F, Molteni R, Calabrese F, Frasca A, Racagni G, Riva MA. Chronic fluoxetine administration inhibits extracellular signal-regulated kinase 1/2 phosphorylation in rat brain. J Neurochem 2005;93:15511560 .

20. Mostany R, Valdizán EM, Pazos A. A role for nuclear beta-catenin in SNRI antidepressant-induced hippocampal cell proliferation. Neuropharmacology 2008;55:18-26.

21. Shors TJ, Miesegaes G, Beylin A, Zhao M, Rydel T, Gould E. Neurogenesis in the adult is involved in the formation of trace memories. Nature 2001;410:372-376.

22. Liang J, Slingerland JM. Multiple roles of the PI3K/PKB (Akt) pathway in cell cycle progression. Cell Cycle 2003;2:339-345.

23. Pandey S, Lopez C, Jammu A. Oxidative stress and activation of proteasome protease during serum deprivation-induced apoptosis in rat hepatoma cells; inhibition of cell death by melatonin. Apoptosis 2003;8: 497-508.

24. Charles I, Khalyfa A, Kumar DM, Krishnamoorthy RR, Roque RS, Cooper N, et al. Serum deprivation induces apoptotic cell death of transformed rat retinal ganglion cells via mitochondrial signaling pathways. Invest Ophthalmol Vis Sci 2005;46:1330-1338.

25. Eren I, Naziroğlu M, Demirdaș A, Celik O, Uğuz AC, Altunbaşak A, et al. Venlafaxine modulates depression-induced oxidative stress in brain and medulla of rat. Neurochem Res 2007;32:497-505.

26. Li XM, Chlan-Fourney J, Juorio AV, Bennett VL, Shrikhande S, Bowen RC. Antidepressants upregulate messenger RNA levels of the neuroprotective enzyme superoxide dismutase (SOD1). J Psychiatry Neurosci 2000;25:43-47.

27. Kolla N, Wei Z, Richardson JS, Li XM. Amitriptyline and fluoxetine protect PC12 cells from cell death induced by hydrogen peroxide. J Psychiatry Neurosci 2005;30:196-201.

28. Wu Y, Shang Y, Sun S, Liu R. Antioxidant effect of erythropoietin on 1-methyl-4-phenylpyridinium-induced neurotoxicity in PC12 cells. Eur J Pharmacol 2007;564:47-56.
29. Kane DJ, Sarafian TA, Anton R, Hahn H, Gralla EB, Valentine JS, et al. $\mathrm{Bcl}-2$ inhibition of neural death: decreased generation of reactive oxygen species. Science 1993;262:1274-2177.

30. Kirkland RA, Windelborn JA, Kasprzak JM, Franklin JL. A Bax-induced pro-oxidant state is critical for cytochrome $\mathrm{c}$ release during programmed neuronal death. J Neurosci 2002;22:6480-6490.

31. Han YS, Lee CS. Antidepressants reveal differential effect against 1-methyl-4-phenylpyridinium toxicity in differentiated PC12 cells. Eur J Pharmacol 2009;604:36-44.

32. Nair A, Vaidya VA. Cyclic AMP response element binding protein and brain-derived neurotrophic factor: molecules that modulate our mood? J Biosci 2006;31:423-434.

33. He TC, Sparks AB, Rago C, Hermeking H, Zawel L, da Costa LT, et al. Identification of c-MYC as a target of the APC pathway. Science 1998; 281:1509-1512.

34. Shtutman M, Zhurinsky J, Simcha I, Albanese C, D’Amico M, Pestell R, et al. The cyclin D1 gene is a target of the beta-catenin/LEF-1 pathway. Proc Natl Acad Sci U S A 1996;96:5522-5527.

35. Ishola TA, Kang J, Qiao J, Evers BM, Chung DH. Phosphatidylinositol 3-kinase regulation of gastrin-releasing peptide-induced cell cycle progression in neuroblastoma cells. Biochim Biophys Acta 2007;1770:927932.

36. Chen B, Pan H, Zhu L, Deng Y, Pollard JW. Progesterone inhibits the estrogen-induced phosphoinositide 3-kinase $\rightarrow$ AKT $\rightarrow$ GSK-3beta $\rightarrow$ cyclin D1 $\rightarrow$ pRB pathway to block uterine epithelial cell proliferation. Mol Endocrinol 2005;19:1978-1990.

37. Hsu YL, Kuo PL, Lin CC. The proliferative inhibition and apoptotic mechanism of Saikosaponin D in human non-small cell lung cancer A549 cells. Life Sci 2004;75:1231-1242.

38. Hsu YL, Kuo PL, Weng TC, Yen MH, Chiang LC, Lin CC. The antiproliferative activity of saponin-enriched fraction from Bupleurum Kaoi is through Fas-dependent apoptotic pathway in human non-small cell lung cancer A549 cells. Biol Pharm Bull 2004;27:1112-1115.

39. Koo JW, Russo SJ, Ferguson D, Nestler EJ, Duman RS. Nuclear factorkappaB is a critical mediator of stress-impaired neurogenesis and depressive behavior. Proc Natl Acad Sci U S A 2010;107:2669-2674.

40. Lucassen PJ, Meerlo P, Naylor AS, van Dam AM, Dayer AG, Fuchs E, et al. Regulation of adult neurogenesis by stress, sleep disruption, exercise and inflammation: Implications for depression and antidepressant action. Eur Neuropsychopharmacol 2010;20:1-17. 